\title{
Economic review
}

\section{July 2009}

Graeme Chamberlin

\section{Office for National Statistics}

\section{SUMMARY}

The UK recession started earlier and is deeper than previously thought, according to newly revised data. In the last year, Gross Domestic Product (GDP) has fallen by 4.9 per cent, the largest four-quarter fall on record. However, some indicators are suggesting that during the second quarter of 2009 the pace of contraction has slowed.

Looking at the demand-side of the economy - fixed investment and de-stocking have been the main drivers of the recession. The financial balance sheets of households and firms indicate that a retrenchment in spending is occurring in order to pay down debts. However, the public sector finances have been hit by the recession generating a large rise in government borrowing. The balance of payments shows a widening current account deficit due to weaker investment income. But the revaluation of foreign assets following the depreciation of sterling has seen the international investment position move into surplus for the first time in over ten years.

\section{GROSS DOMESTIC PRODUCT}

\section{New data shows UK recession is deeper and started earlier}

ublication of the Quarterly National Accounts marks the third vintage of data relating to the first quarter of 2009. Not only are these figures based on higher information content as forecasts and imputations are replaced by hard data, giving a more complete description of trends in the UK economy, they are also consistent with this year's Blue Book. The Blue Book is an annual publication where previous data is benchmarked to annual surveys, and for earlier years, input-output analysis is undertaken to track supply and demand at a detailed product and industry level.

Data revisions therefore reflect the adoption of new information into the National Accounts that were previously unavailable for earlier data vintages.

Two main results have emerged from the

\section{Figure 1 GDP growth}

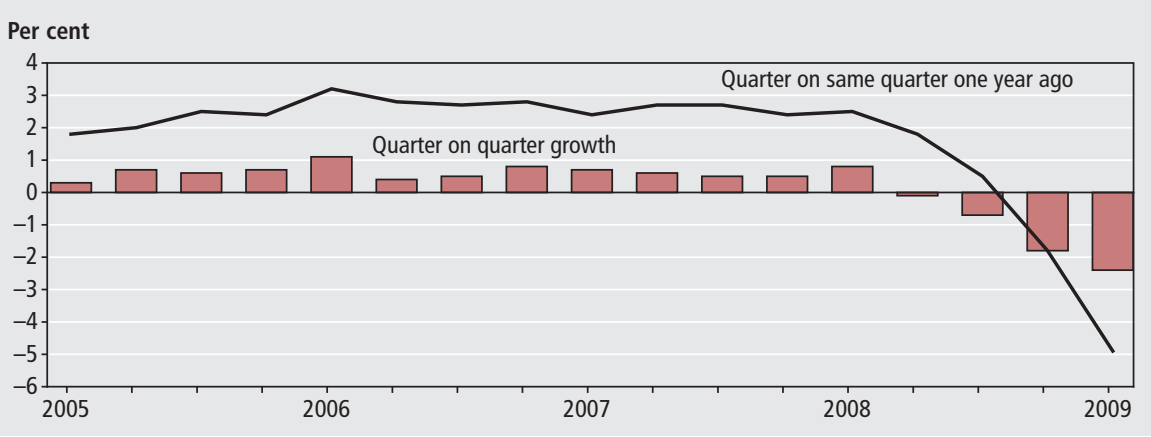

Source: ONS Quarterly National Accounts process. First the recession in the UK economy started earlier. Gross Domestic Product (GDP) had previously been estimated as flat in 2008 Q2, but is now estimated to have fallen by 0.1 per cent, meaning the UK economy has shrunk for four successive quarters (see Figure 1). If the technical definition of a recession is two consecutive quarters of negative growth, then the recession now started in the third quarter of last year.

More dramatically, data for the first quarter of 2009 have been revised significantly downwards. Last month's 'Output, Income and Expenditure' release reported that GDP had fallen by 1.9 per cent during the quarter. New estimates though indicate the pace of contraction was actually faster, with output falling by 2.4 per cent. Such a quarterly contraction has only been experienced on two prior occasions in the last 50 years (1974 Q1 and 1979 Q3), and both were the result of significant oil price shocks.

On a four-quarter basis, that is comparing GDP in 2009 Q1 relative to the first quarter in 2008, output has fallen by 4.9 per cent, the largest drop on record. The current recession is already more severe than that of the early 1990s when the economy posted a total peak to trough fall in output of about 2.5 per cent. Parallels have been drawn with the recession of the early 1980s, which also saw the major global economies fall into a synchronised recession resulting in a considerable downturn in world trade, but the new data shows UK output is currently falling faster than at this time. However, whether the overall output loss will or will not exceed the peak to trough fall of 6 per cent (1979 Q2 to 1981 Q1) largely depends on the duration of the current downturn and the speed of the recovery.

Hopes of a recovery have been subdued by the latest data which shows the recession to be deeper than previously thought. But of course, the end of the first quarter was some months ago, and indicators since have suggested that even if a recovery is not already underway there has at least been a moderation in the speed of the downturn. In May the Index of Manufacturing was flat - bringing to an end a 12-month run of falling output. Furthermore, a number of business surveys 


\section{Figure 2}

\section{Contributions to economic growth by industry, 2009 Q1 ${ }^{1}$}

Per cent

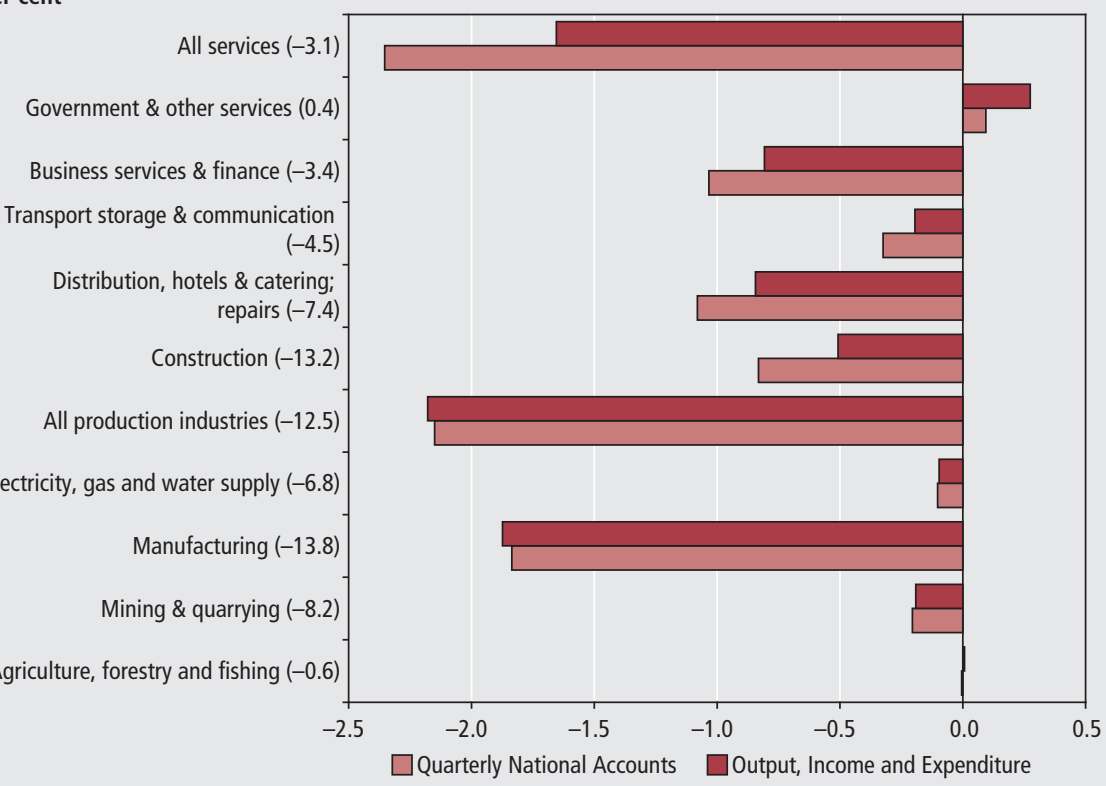

Note:

Source: ONS Quarterly National Accounts and Output, Income and Expenditure

1 Actual four-quarter growth rates from the Quarterly National Accounts are shown in brackets.

Figure 3

Contributions to growth by service sector industry, 2009 Q11

Per cent

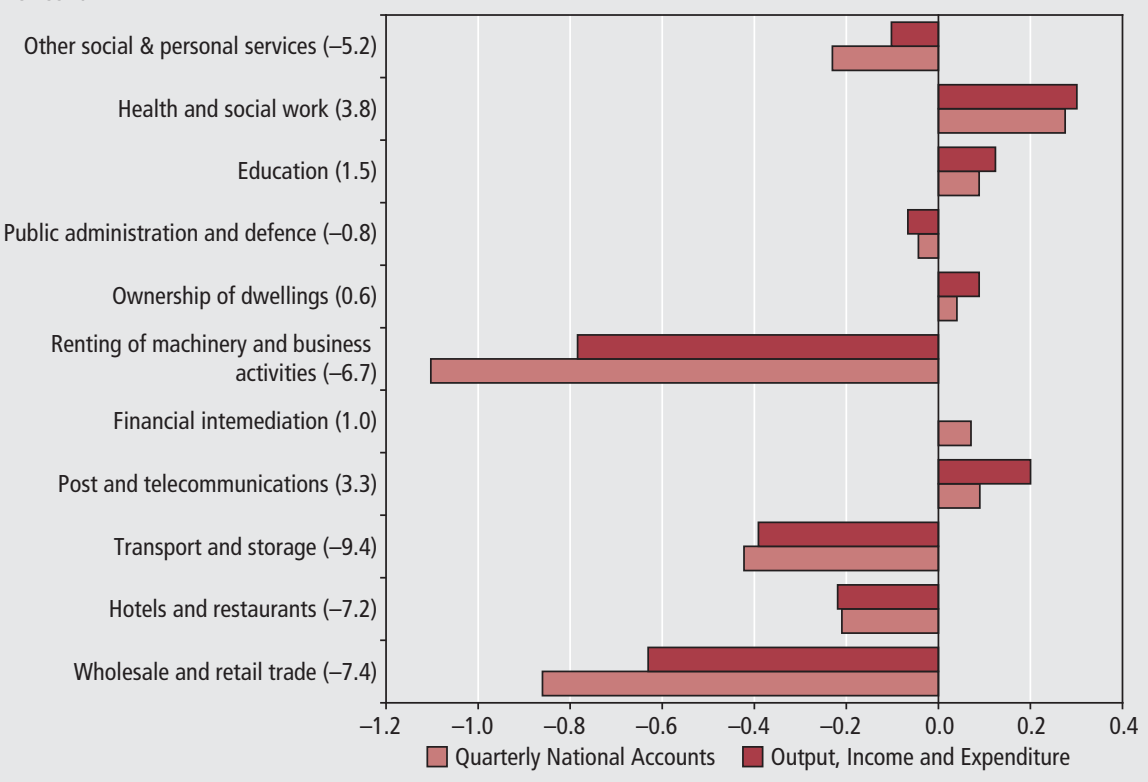

Note:

Source: ONS Quarterly National Accounts and Output, Income and Expenditure

1 Actual four-quarter growth rates from the Quarterly National Accounts are shown in brackets.

have reported that although sentiment remains poor, it is not as weak as it has been and the worst may have passed. The National Institute of Economic and Social Research have even gone as far as saying growth returned in April. Preliminary estimates of GDP for the second quarter of 2009, published towards the end of July, will be eagerly awaited to see if official data confirms the view that the UK economy is nearing a turning point.

\section{Services and construction weaker than previously thought}

\footnotetext{
ross Value Added (GVA) is a

production-based measure of activity used in the estimation of
} GDP. It seeks to measure the contribution of each firm, industry or sector to the total value of goods and services produced, essentially by estimating the value of the output less the value of the inputs at each stage of production. GDP is basically this measure at market prices, so GVA needs to be adjusted for the impact of taxes and subsidies on prices. Revisions to GVA should therefore give an indication as to the sources of the latest GDP revisions.

In the Output, Income and Expenditure release (the second vintage of National Accounts data for a specific quarter) GVA was 4.2 per cent lower in 2009 Q1 than in the same quarter of 2008. For the same period, GVA was estimated to have fallen by 5.2 per cent in the recently published Quarterly National Accounts. Figure 2 shows the contributions by industry to these two results. It can be seen that the majority of the downward revision is accounted for by the construction and services sectors.

The downward revision to construction output reflects actual data replacing forecasts in the Quarterly National Accounts. On a four-quarter basis construction activity is now estimated to have fallen by 13.2 per cent, compared to the earlier estimate of 8.6 per cent. Only the manufacturing industry has experienced a bigger loss of output in the last year. Sharp declines in the private house building sector have been behind the trend.

Service sector output, which accounts for approximately three-quarters of the UK economy, are now estimated to have fallen by 3.1 per cent in the four quarters to 2009 Q1 - a much stronger decline than the previous 2.2 per cent estimate. In fact, the downturn in the services sector had been relatively modest compared to other sectors before these revisions. Figure 3 provides a further breakdown of the contributions of each service sector industry to overall GDP growth. The wholesale and retail, and renting of machinery and business activities have accounted for the majority of the downward revision - indicating that both consumer and business demand have been weaker than initially estimated.

\section{Fixed investment and de- stocking lead the fall in total expenditure}
$\Lambda$ breakdown of the 4.9 per cent fall in GDP between 2008 Q1 and 2009 Q1 by main category of expenditure is shown in Figure 4. This shows a fairly mixed pattern, with some components contributing negatively to growth and others positively.

Gross fixed capital formation (GFCF), which is investment spending on physical assets, has fallen sharply in the recession. 


\section{Figure 4}

\section{Contributions to growth by category of expenditure, 2009 Q1}

Per cent

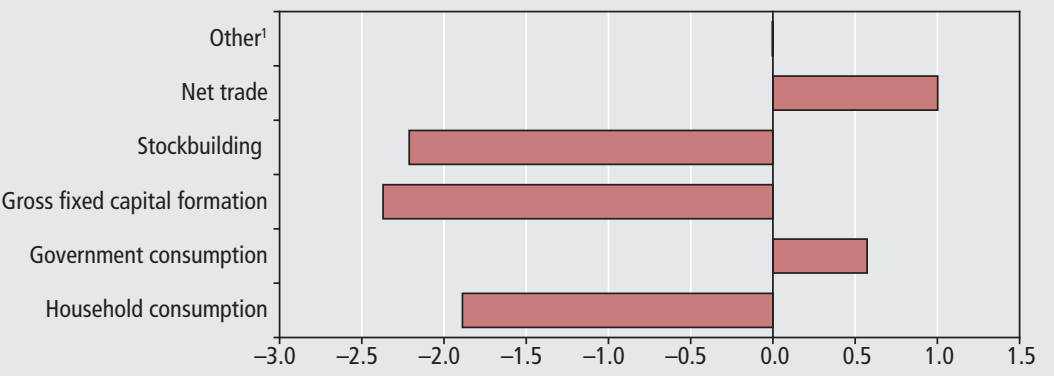

Note:

Source: ONS Quarterly National Accounts

1 Other category of expenditure consists of expenditure by non-profit institutions serving households (NPISH), acquisition less disposals of valuables and the statistical discrepancy. by 13.2 per cent in 2009 Q1 on a four quarter basis, making the largest single expenditure-based contribution to the downturn.

Firms looking to run down inventories in response to depressed order books have also made a significant contribution to falling expenditure. In level terms inventories, or stockbuilding, are a miniscule component of aggregate demand but often play an important role in accounting for changes. Inventory patterns also tend to be procyclical and often a leading indicator of economic activity. In a recession, companies expecting to cut future production will seek to lower their stocks of finished goods, semi-finished goods and raw materials. De-stocking can also be quite aggressive if firms perceive the downturn to be deep and/or prolonged as in this case. However, when the economy reaches a turning point inventories would be expected to rise equally quickly as firms look to increase future production.

Household spending is the largest part of total expenditure and, as such, plays an important role in driving expenditure patterns even if it doesn't usually exhibit the same degree of pro-cyclical behaviour as GFCF and stockbuilding. Household consumption fell by 3.1 per cent in the year to 2009 Q1, pulling down GDP growth by approximately 1.9 percentage points. The weakening labour market and the desire to rebuild or strengthen balance sheets by repaying debt appear to be the main factors accounting for falling expenditure.

Positive contributions to GDP growth though came from government consumption spending and net-trade. General government spending grew by 2.8 per cent over the four-quarter period, without which, the contraction in GDP would have been 0.6 percentage points greater. It is not surprising that government
According to the latest figures, GFCF fell spending has been fairly immune to the downturn. Spending on certain transfer payments will tend to rise in line with unemployment anyway as part of the automatic stabilisers built into the public finances. Even the more discretionary elements of spending are likely to be robust, with spending plans set in advance and the government unwilling to make drastic cuts while the economy is in recession.

Net trade represents the difference between exports, which add to GDP, and imports which detract. On a four-quarter basis, net trade added 1 percentage point to GDP in 2009 Q1. This has been because the 13.6 per cent fall in imports over this period has outstripped the corresponding 11.6 per cent fall in exports. But although the impact on GDP has been positive it is not necessarily all good news. In fact it might be an indicator of the relative severity of the UK recession vis-à-vis other countries and the extent of imbalances in the economy prior to the downturn. In this case the improvement in net trade is a reflection of the size of correction required in the UK economy, in particular a rebalancing away from consumption to saving and imports to exports.

It is difficult to tell the extent to which sterling's depreciation has been beneficial for UK trade. As business surveys suggest, any boost to exports has been strongly outweighed by the sharp fall in global demand and world trade, so the impact is likely to be small. However, this doesn't rule out the possibility that the fall in exports could have been even worse had it not been for the exchange rate depreciation.

\section{HOUSEHOLD SECTOR}

\section{Household consumption spending falls}

\section{n 2009 Q1 household consumption fell by 3.1 per cent relative to the same quarter in 2008. A breakdown of this} aggregate figure, by category of spending, is shown in Figure 5.

A first and striking observation from Figure 5 is the contribution to the fall in household spending from net tourism. This is the difference between the spending of UK tourists overseas and the spending of foreign tourists in the UK. Since the first quarter of last year, net tourist spending

\section{Figure 5 \\ Contributions to household consumption by category of spending, 2009 Q1 1}

\section{Per cent}

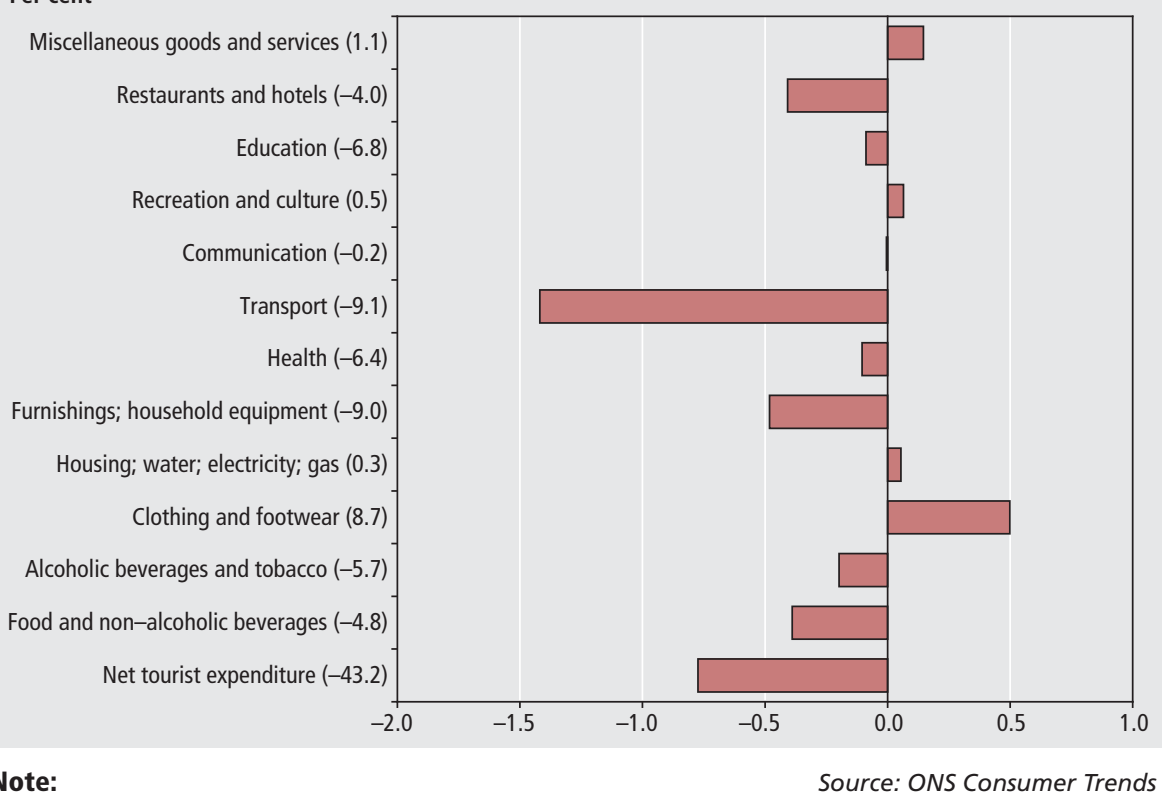

1 Actual four-quarter growth rates for each component are shown in brackets. 
has nearly halved, making a 0.8 percentage point contribution to the total fall in household consumption.

While foreign tourist spending in the UK fell by 7 per cent, UK tourist spending abroad fell by a much larger 23.1 per cent. Sterling depreciation, making overseas travel relatively more expensive, may be one factor accounting for these trends. However, the sharp fall in UK tourist spending abroad is more likely to reflect a strong retrenchment in discretionary spending by a cautious household sector looking to repay debt and facing a deteriorating jobs market.

The largest downward contribution came from the transport category where a four-quarter fall in spending of 9.1 per cent dragged total consumption growth down by 1.4 percentage points. Within this category the purchase of motor vehicles showed an especially sharp fall, with spending on cars down by 12.2 per cent. This is not surprising given the dire news emanating from the car industry of late, although the new car scrapping scheme introduced in the Budget seems to be stimulating some recovery in the second quarter. Weak consumer confidence with regard to major purchases and a tightening of credit availability are likely to have hurt demand. Air transport, which fell by 10.1 per cent, also made a significant negative contribution within this category.

Spending on furnishings and furniture fell by 9 per cent and within this category there was a 15.4 per cent fall in spending on home furnishings and an 11.6 per cent fall in spending on household appliances. Once again demand for these items, being largely discretionary purchases, will be particularly sensitive to the current economic climate. Additionally, the considerable slowdown in the housing market, in particular low turnover in sales, is likely to impact negatively on these expenditure items. Spending in restaurants and hotels and on food and non-alcoholic beverages both accounted for approximately 0.4 percentage points to the total fall in household consumption.

While food spending fell by 4.8 per cent in real terms, in value or current price terms it actually rose by 5.2 per cent. The implied deflator estimates that prices of food and non-alcoholic beverages grew by 10.6 per cent between the first quarters of 2008 and 2009 and suggests relative price movements may have played an important role in explaining consumer trends over the last year. In response to rising food prices households actually increased food spending, but also cut back in terms of quantities.

Other areas where there were significant prices increases last year saw a similar divergence between real and nominal household spending. Electricity and gas prices rose sharply, so while in real terms spending was broadly flat, in value terms it increased significantly. Similarly, large swings in petrol prices have seen volatile nominal spending on transport fuels while in real terms spending has been far more stable. This could of course have had a knock on impact on other components of consumer spending, especially the more discretionary parts, by reducing the real value of household disposable income.

This factor seems to have worked in reverse for clothing and footwear, where spending grew by 8.7 per cent last year in real terms boosting overall household spending by about 0.5 percentage points. However, this was aided by a 6.5 per cent fall in prices, so in nominal terms spending growth was far more modest. Therefore it appears to be the case that stronger spending here has been driven by significant discounting.

A similar pattern emerges when looking at UK retail sales data. Due to the sharp rise in food prices, spending in predominately food stores has grown in value terms

\section{Figure 6}

\section{Household saving ratio and net-borrowing}

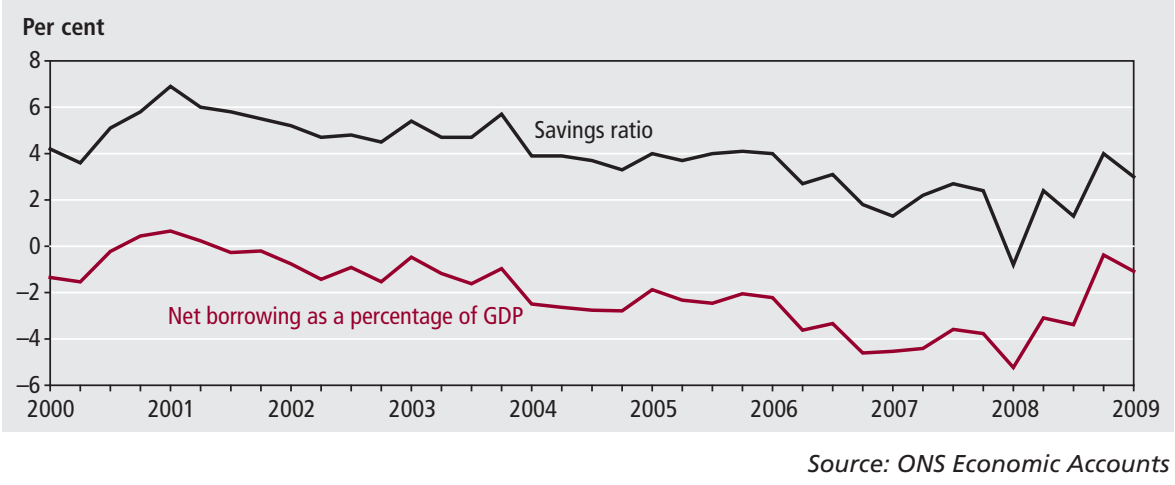

but fallen in volume terms. At the same time, strong discounting has meant that spending in predominately non-food stores are showing the opposite trends, growing in volume terms but not in value terms. This certainly goes some of the way to explaining why, in volume or real terms, retail sales have so far been fairly robust in the downturn.

\section{Household savings ratio, despite edging upwards recently, remains historically low}

T he UK household saving ratio was 3 per cent in 2009 Q1. Although this

lies far below the long-term average, it does reflect a slight pick up from the very low rates that have prevailed in the UK economy over the last two years and a reversal of the long decline in the ratio that started in 2001 (see Figure 6).

Recent increases in household saving have certainly been influenced by falling consumer spending, which is the counterpart to household saving. However, it has also been driven by an increase in household resources, increasing the funds available for consumption or saving. It may seem strange, given the current economic climate, that the household sector has seen available resources increase.

Wages and salaries have fallen in line with the weakening labour market, as have operating surpluses from small household businesses and the self-employed. Though, in terms of household balance sheets, these have been slightly offset by lower tax payments and also greater social transfers (benefits payments).

The main factor accounting for the rise in household resources are property income flows. These are payments or receipts to other sectors of the economy generated by ownership of financial assets or liabilities. For example, household property income may come from interest payments on financial assets or dividends from equities. However, in the household balance sheets these are also netted out against payments of property income paid by the household sector in lieu of its liabilities to other sectors. Because households hold a large amount of mortgage debt connected with home ownership, the large fall in interest rates in the last year will have significantly reduced the cost of servicing mortgage debt.

In the household accounts this will show up as an increase in net property income 
(because household interest payments have fallen) hence increasing available resources. But the evidence suggests that increased household resources has not translated into growing consumption. Instead the household sector appears to be increasing savings and paying back of debts. There are widespread reports that many households are now overpaying their mortgages following the sharp reduction in mortgage rates since last autumn.

A further impact of housing market developments on the household sector balance sheet is also shown by its net lending position (see Figure 6). A sector is a net lender, or borrower, if the funds it generates internally (meaning the resources left over after uses) are sufficient or insufficient to cover the investment plans of that sector. For example, if funds are insufficient then the sector becomes a net borrower, needing to borrow from other parts of the economy to fund its desired investment.

For the household sector investment mainly takes the form of owner-occupied housing, which provides a stream of future housing services to the buyer. Unsurprisingly the household sector is usually a net borrower, because gross saving are insufficient to cover investment, mainly in property so most houses are purchased using mortgage debt. However, as Figure 6 shows, household net borrowing has fallen sharply in the last year, and the household sector has come close to actually becoming a net lender. This partly reflects the rise in gross savings brought about by falling consumption and reduced interest payments. But the main factor has been the fall in household investment due to significant slowdown in house purchases. Lending for home purchases has fallen sharply, a consequence of tightening credit conditions and weak demand brought on by rising unemployment and falling property values. As a result the UK household sector has dramatically cut its borrowing which is reflected in the net borrowing/lending figures.

PRIVATE SECTOR CORPORATIONS AND INVESTMENT

\section{The housing market drives the fall in fixed investment}

igure 4 shows GFCF fell by 13.2 per cent
in the four quarters to 2009 Q1, making
the largest single contribution to the downturn in expenditure-based GDP. A breakdown by sector is shown in Figure 7 .
Business investment has fallen by 9.7 per cent during the year reflecting weak economic conditions and the pessimistic outlook of firms. Although credit has been tightened, and this has been identified as an increasingly important factor behind lower investment intentions in business surveys, it is by no means the most influential factor. Instead it is uncertainty over future demand that has caused firms to take a cautious view with regard to investment plans. Therefore it is the recessionary effects of weak demand and uncertainty that appears to be having the major impact on investment spending rather than shortages of available credit.

General government investment has slightly offset the large fall in private sector investment. In the four quarters to 2009 Q1 it rose by 1.8 per cent and is further evidence of the relative robustness of the public sector to the current recession. Investment spending may have been buoyed by the government's intention to bring forward some capital spending as part of the fiscal stimulus package announced in the 2008 Pre-Budget Report.

However, the largest contribution to the fall in fixed investment has been related to the falling housing market. Dwellings and existing buildings category reflects investment in the construction of new dwellings, improvements to existing dwellings, and the costs associated with the transfer of buildings, dwellings and the ownership of non-produced assets (land). Between the first quarters of 2008 and 2009 a 28.3 per cent was recorded in this category of spending, mainly reflecting the marked fall in the house building sector. These figures are consistent with the large fall in construction output, and the reduction in investment recorded on household balance sheets.

\section{Private non-financial corporations increase net lending}

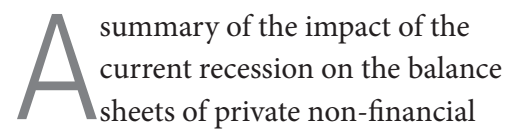
corporations (PNFC) is shown in Figure 8. This basically presents recent trends in the net lending position of the PNFC sector, which is the difference between resources available for investment and actual investment undertaken.

Resources available for investment mainly reflect the income generated by

\section{Figure 7}

\section{Contributions to the fall in fixed investment, 2009 Q1 ${ }^{1}$}

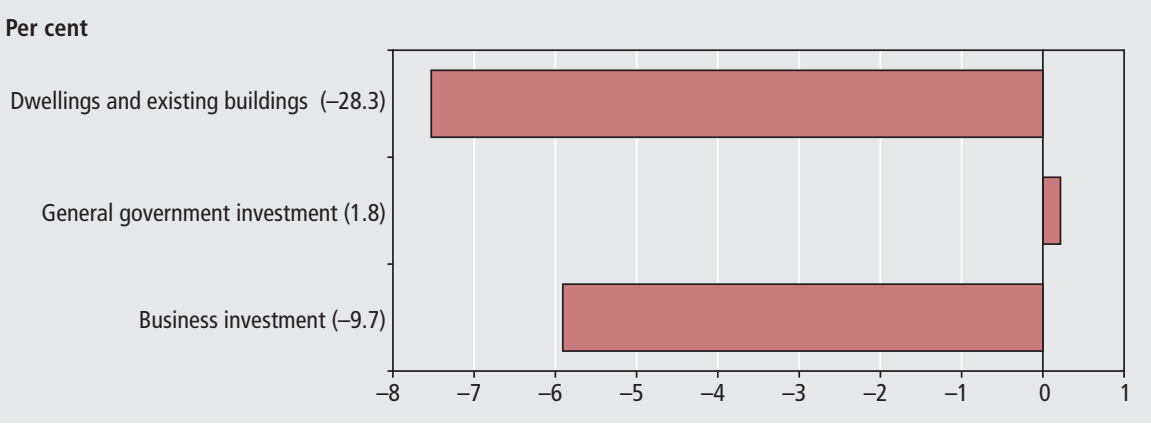

Note:

Source: ONS Quarterly National Accounts

1 Actual four-quarter growth rates for each component are shown in brackets.

\section{Figure 8 \\ PNFC net-lending}

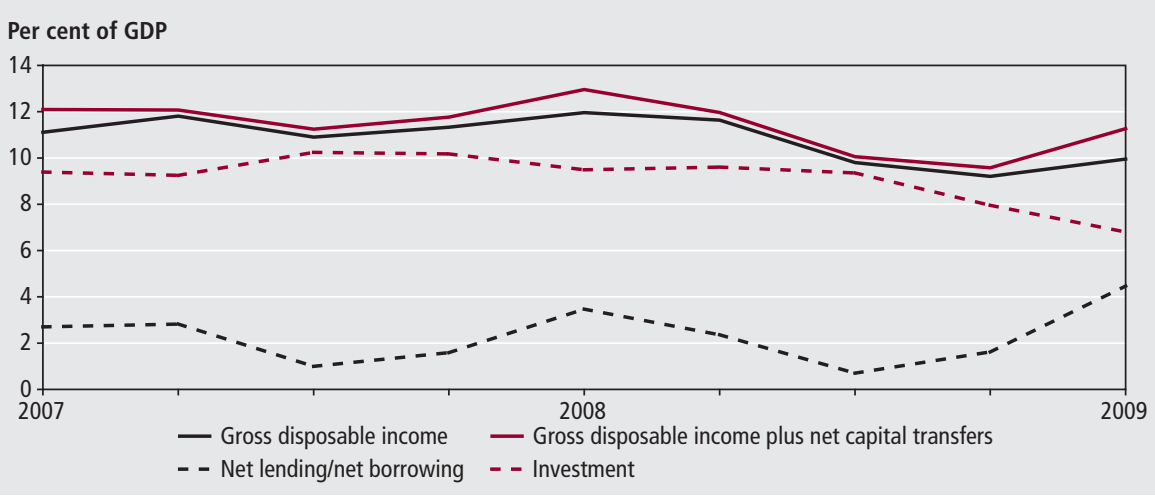

Source: ONS Economic Accounts 
corporations and have fallen as a proportion of GDP in the last year. While operating surpluses (profits) seem to have held up reasonably well, there has been a big fall in property income which had been making a significant contribution in recent years to overall PNFC income. Property income reflects the net income payments associated with the ownership of financial assets, and have fallen considerably in the last year mainly due to a sharp reduction in earnings from foreign direct investments. This though has been partially offset by a fall in the net interest payments paid by the sector as global interest rates fall. Total PNFC resources though were boosted in 2009 Q1 by investment grants, which accounts for the main difference between PNFC disposable income and total resources shown in Figure 8.

Net-lending as a proportion of GDP has risen because the uses of these funds have fallen at an even faster rate, a reflection of the slowdown in corporate sector investment. Here, investment includes not just fixed investment (GFCF) in capital assets, but also the disposal of inventories (negative stockbuilding) which, in terms of the PNFC balance sheet, shows firms to be running down their working capital (or reducing their assets). Therefore recent trends in PNFC balance sheets are picking up the stories of weak investment and the rapid de-stocking that have been recorded in other parts of the National Accounts.

\section{BALANCE OF PAYMENTS}

\section{Investment income weakens the current account}

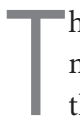

he Balance of Payments records one nation's transactions with the rest of the world. The current account records main economic flows relating to trade, income and transfers, whereas the financial account records international transactions in financial assets and the funding of the current account.

Figure 9 plots the recent history of the current account and its main constituent parts. In sum, the UK current account has deteriorated throughout 2008 and into 2009. At the end of the first quarter of 2009 , the UK current account stood in deficit of 2.5 per cent of GDP compared to a deficit of 0.7 per cent at the start of 2008 .

The growing UK current account deficit has occurred despite an improvement in the trade balance. The balance of trade in goods has closed to around 6 per cent of GDP. Although exports of UK goods have fallen, imports have fallen even faster, mainly as a result of the sharp slowdown in global manufacturing trade. Deficits in goods trade have historically been partly offset by surpluses in services trade. These have remained robust despite the global economic downturn. In fact exports and imports of services have not changed dramatically in the course of the last year. Significant positive contributions have continued to come from exports of financial services and royalties and licence fees. The improvement in the UK trade balance is consistent with the positive contribution of net trade to GDP growth.
The two other components of the current account are transfers and income flows. Transfers relate to items such as international aid and membership of supranational organisations such as the European Union and the United Nations. As a proportion of GDP this category is relatively constant, so doesn't usually account for changes in the overall current account. Income flows though are more important. This item accounts for remittances of workers, but the majority is investment income flows associated with the ownership of international assets.

Investment income has generally made

\section{Figure 9}

\section{UK current account}

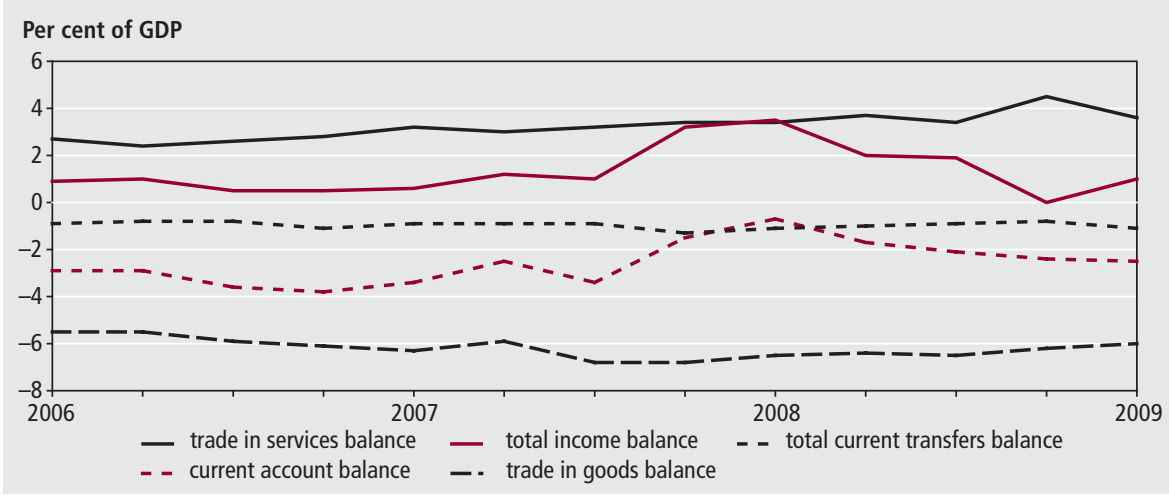

Source: ONS Balance of Payments

\section{Figure 10}

\section{UK International investment position}

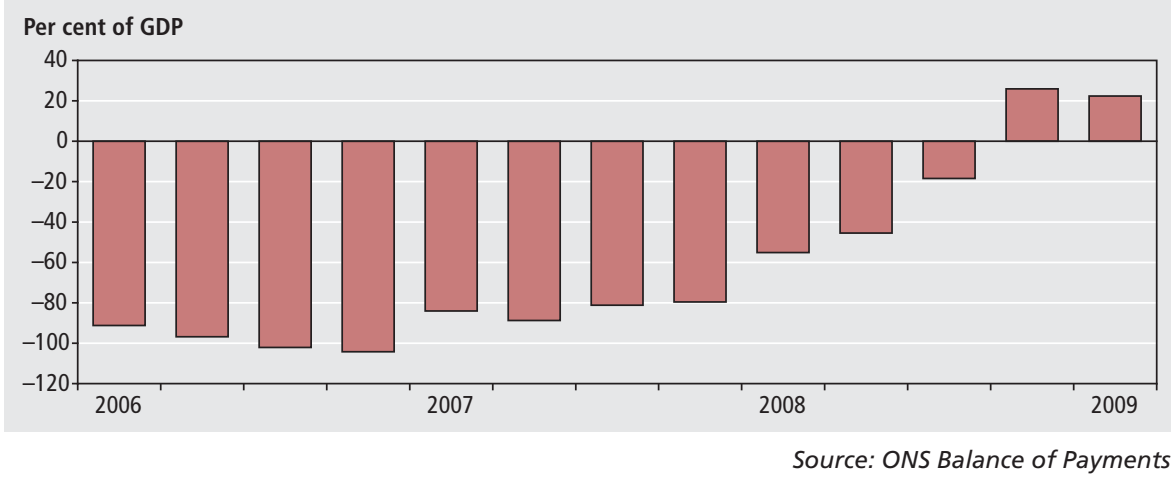

Figure 11

\section{UK Net lending/net borrowing by sector}

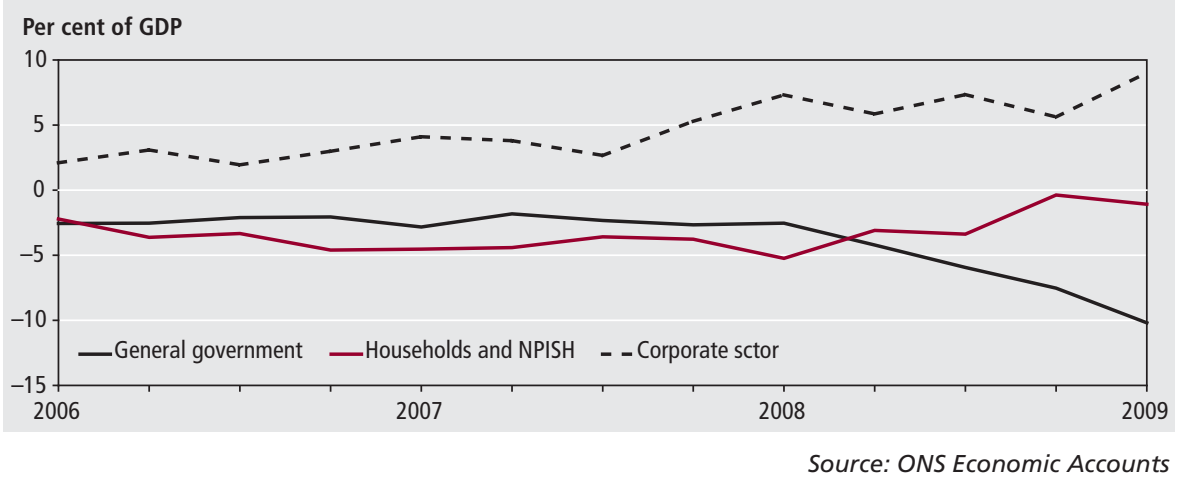


an important positive contribution to the National Accounts, largely reflecting the large positive net stock of foreign direct investments held by UK firms and institutions. However, this component also tends to be more volatile and pro-cyclical. The fall in the UK current account deficit at the end of 2007 and the beginning of 2008 was driven by strong investment income, but in recent quarters this has gone into quick reverse. These trends in investment income have also been reflected in the balance sheets of UK private non-financial corporations, where earnings from foreign direct investment have fallen sharply since the start of the global recession.

\section{International Investment Position turns positive}

- he international investment position

(IIP) is essentially the net balance

in the ownership of international financial assets. As financial globalisation has progressed over the last three decades, stocks of foreign assets and liabilities have grown considerably as proportions of GDP. The UK has generally run a negative IIP in the last decade as a consequence of persistent current account deficits. The funding of these either requires the accumulation of financial liabilities or the disposal of foreign assets, both of which will raise foreign liabilities relative to foreign assets and reduce the IIP.

Despite this, and rather curiously, the UK has still generally been able to produce positive investment income - so a negative stock of assets is consistently generating positive net investment incomes. The explanation appears to be in the composition of the UK's IIP with the UK generally holding a surplus in relatively high earning but volatile direct investment assets and a deficit in lower earning interest bearing assets. The UK's net asset position in direct investment accounts for the sensitivity of its investment income flows in the current account, especially as global profitability falls in the current world-wide downturn.

However, in the final quarter of 2008 and the first quarter of 2009 the UK's IIP moved into positive territory for the first time since 1995, even though the current account deteriorated (see Figure 10). Although IIP is partly determined by international flows connected with funding the current account, the actual position is also subject to revaluations connected with changing asset prices. Here the recent depreciation of sterling has had a profound impact in raising the sterling value of foreign assets denominated in foreign currency. As the UK can largely borrow in its own currency, depreciation has little effect on the corresponding sterling value of liabilities.
UK SECTORAL BALANCE SHEETS

\section{Retrenchment by all apart from the government}

\author{
- inancial and Sector Accounts, \\ published along side the National \\ Accounts, provide detailed
} information on the balance sheets of the main sectors in the UK economy. The current financial crisis and economic recession has the raised the value of these in macroeconomic analysis. A summary of the financial position of each sector can be seen by movements in its net lending or net borrowing position. As Figure 11 shows, while households and private corporations (financial and non-financial) have shown evidence of retrenchment in looking to reduce debt, the government has been the exception. Sharp rises in government net borrowing reflect the growing budget deficits and rising public debt as the recession hits the public sector finances.

In the recent Budget Report, the current budget balance is not projected to return to surplus until the financial year 2016/17, during which time public sector net debt will double to over 70 per cent of GDP. Most commentators and forecasters though are predicting a strong contraction in fiscal policy after the next general election. 